\title{
Cemaran Bakteri dan Residu Antibiotika Daging Babi di Pasar Tradisional Kecamatan Abiansemal dan Kuta Kabupaten Badung
}

\author{
(BACTERIAL CONTAMINATION AND ANTIBIOTIC RESIDUE ON PORK IN WET \\ MARKETS IN ABIANSEMAL AND KUTA DISTRICTS IN BADUNG REGENCY)
}

\author{
I Made Arthawan ${ }^{1 *}$, Hapsari Mahatmi ${ }^{2}$, I Nengah Kerta Besung ${ }^{2}$ \\ ${ }^{1}$ Dinas Pertanian dan Ketahanan Pangan Provinsi Bali, Jl. WR Supratman No. 71, Kesiman, Denpasar \\ Timur, Denpasar, Bali; ${ }^{2}$ Laboratorium Bakteriologi Veteriner, Fakultas Kedokteran Hewan, \\ Universitas Udayana, Jl. PB Sudirman, Denpasar, Bali. \\ *Email: imade.arthawan@gmail.com
}

\begin{abstract}
Abstrak
Penelitian ini bertujuan untuk mengetahui tingkat cemaran bakteri dan residu antibiotik daging babi, serta memberi gambaran penanganan daging yang dijual di pasar tradisional di Kecamatan Abiansemal dan Kuta, Badung. Penelitian ini merupakan studi cross-sectional menggunakan kuisioner dan pengujian cemaran bakteri dan residu antibiotik daging babi. Data kuisioner dan sampel daging dikumpulkan dari 26 penjual dari 8 pasar tradisional, selanjutnya data dianalisis secara deskriptif. Uji cemaran bakteri dilakukan dengan menghitung nilai Total Plate Count, Coliform, Escherichia coli, Salmonella sp, Staphylococcus aureus, dan Campylobacter sp. Uji residu antibiotik dilakukan dengan metode tapis secara bioassay terhadap antibiotik tetrasiklin dan penisilin. Hasil menunjukkan nilai rerata Total Plate Count 3,7 x $10^{5}$ dengan kisaran 7,3 × 10 $-1,5 \times 10^{6}$ koloni/gram. Rerata Coliform dan Escherchia coli adalah 1,3 x $10^{5}$ dan 2,1 x $10^{4}$ dengan kisaran $1,1 \times 10^{3}-4,4 \times 10^{5}$ koloni/gram dan $4,5 \times 10^{1}-9,7 \times 10^{4} \mathrm{koloni} /$ gram. Cemaran Staphylococus aureus adalah negatif hingga $2 \times 10^{1}$ koloni/gram. Cemaran Salmonella $s p$ dan Campylobacter sp. adalah negatif. Residu antibiotik tetrasiklin dan penisilin masing-masing sebesar 15,38\% dan 11,54\% dari seluruh sampel daging babi. Tingkat pemahaman dan kesadaran masyarakat terhadap penanganan dan sanitasi daging adalah $50 \%$ responden kategori cukup dan 50\% kategori kurang paham dan kurang sadar tentang sanitasi. Faktor yang mempengaruhi tingkat cemaran bakteri yaitu tindakan praktik higiene dan sanitasi penjual daging babi yaitu 7,7\% kategori baik, 80,8\% kategori cukup dan 11,5\% dengan kategori kurang. Disimpulkan bahwa daging babi di pasar tradisional Kecamatan Abiansemal dan Kuta Kabupaten Badung tercemar bakteri dan mengandung residu antibiotik, serta dilihat dari aspek kesehatan masyarakat veteriner tidak layak untuk dikonsumsi.
\end{abstract}

Kata kunci: cemaran bakteri; residu antibiotic; Abiansemal; Kuta

\begin{abstract}
This study aimed to determine the bacterial contamination and antibiotic residues on pork and provided an overview of the handling conditions of pork sold in wet markets in the Abiansemal and Kuta, Badung traditional markets. This study was a cross-sectional study using questionnaires and testing bacterial contamination and antibiotic residues in pork. Questionnaires and pork samples were collected from 26 pork sellers from 8 wet markets, then the data were discussed descriptively. Bacterial contamination tests were carried out by calculating the value of Total Plate Count, Coliform, Escherichia coli, Salmonella sp, Staphylococcus aureus, and Campylobacter sp. The antibiotic residue test was carried out by a screening method (bioassay) against tetracycline and penicillin antibiotics. The results showed that the mean total plate count was $3,7 \times 10^{5}\left(7,3 \times 10^{3}\right.$ to $1,5 \times 10^{6}$ colonies/gram $)$. The contamination of Coliform and Escherichia coli were 1,3 x $10^{5}$ dan $2,1 \times 10^{4}$ respectively with $(1,1 \mathrm{x}$ $10^{3}$ to $4,4 \times 10^{5}$ colonies/gram) and (4,5 $\times 10^{1}$ to $9,7 \times 10^{4}$ colonies/gram). Contamination of Staphylococcus aureus was the negative results up to $2 \times 10^{1}$ colonies/gram. Contaminations of Salmonella sp and Campylobacter sp were negative. Tetracycline and penicillin antibiotic residues were found in $15.38 \%$ and $11.54 \%$ of all pork samples. The level of public understanding and awareness of the handling and sanitation of pork was found in $50 \%$ of respondents who were in the adequate category
\end{abstract}


and $50 \%$ in the categories lacked understanding and were less aware of sanitation. Factors that influence the level of bacterial contamination were hygiene practices and sanitation practices of pork sellers $7.7 \%$ in the good category, $80.8 \%$ in the moderate category and $11.5 \%$ in the low category. In conclusion, pork in the traditional markets of Abiansemal and Kuta in Badung Regency is contaminated with bacteria and contains antibiotic residues, and from the aspect of veterinary public health, it was not suitable for consumption.

Keywords: bacterial contamination; antibiotic residues; Abiansemal; Kuta

\section{PENDAHULUAN}

Daging babi merupakan bahan pangan asal hewan yang mudah rusak karena mudah tercemar secara biologis dan kimiawi sehingga dapat membahayakan kesehatan manusia. Mikroorganisme penyebab foodborne disease pada daging babi diantaranya Escherichia coli, Salmonella sp, Campylobacter sp, dan Staphylococcus aureus (Baer et al., 2013). Kategori makanan yang memiliki peran penting dalam kejadian foodborne disease terkait wabah terbanyak salah satunya adalah berasal dari babi berkisar 2,670 kejadian (10\%) (Dewey-Mattia et al., 2018). Selain bahaya foodborne disease terdapat juga bahaya kandungan atau residu antibiotika akibat pemberian antibiotika yang tidak terkendali saat pemeliharaan. Keduanya tidak berhubungan langsung namun sangat berpengaruh pada kesehatan konsumen babi.

Sejak awal tahun 2016 masalah residu antibiotika pada produk ternak menjadi perhatian besar oleh pemerintah dan badan kesehatan dunia karena dampaknya yang serius di seluruh dunia. Hal ini karena residu antibiotika yang terkonsumsi melalui daging atau produk hewan akan berakibat resistensi pada manusia yang mengkonsumsi. Antibiotik yang sering digunakan pada peternakan babi di Indonesia adalah penisilin (50\%) dan oxytetracycline $(26,5 \%)$ (Arief et al., 2016). Residu antibiotik pada daging babi telah ditemukan di beberapa negara seperti di Vietnam dengan residu antibiotik sulfamethazine, penicillin dan oxytetracycline, sementara di Malaysia residu antibiotik tetracyclines, sulphonamides dan quinolones (Do et al., 2016; Marni et al., 2017).

Masyarakat, khususnya penjual makanan khas bali, mendapatkan bahan baku daging babi untuk dimasak umumnya dari pasar-pasar tradisional yang ada di wilayahnya. Demikian pula penjual makanan khas bali di wilayah Kuta dan Abiansemal memperoleh daging babi dari pasar tradisional di wilayah masingmasing. Umumnya pasar tradisonal meskipun saat ini secara fisik telah dilakukan penataan, namun kesadaran masyarakat masih rendah akan pentingnya sanitasi dan higiene bagi kesehatan. Salah satu faktor terpenting yang mempengaruhi mutu kesehatan daging babi adalah pada level pemasaran dalam bentuk retail ke masyarakat yang dilakukan oleh penjual secara tradisonal.

Sampai saat ini dinas setempat telah berupaya untuk terus meningkatkan kualitas dan kuantitas dengan melaksanakan penyuluhan akan penggunaan antibiotik pada peternakan serta pemeriksaan rutin baik pada babi hidup maupun pada proses pemotongannya sesuai dengan standar operasional prosedur (SOP) dan standar yang berlaku. Secara umum daging babi yang keluar dari rumah pemotongan hewan (RPH) telah memenuhi kriteria dan aman dikonsumsi. Namun setelah sampai pada tingkat pengecer di pasar-pasar kualitas daging babi belum pernah dilakukan pemantauan secara rutin, sehingga sedikitnya data ilmiah tentang kondisi kualitas daging babi yang beredar di pasaran baik dari segi residu antibiotik ataupun cemaran bakteri yang membahayakan manusia. 
Penelitian ini dilakukan untuk mengetahui tingkat kualitas daging babi, sebagai dasar untuk menyusun strategi dan tindak lanjut pemerintah setempat dalam upaya meningkatkan perekonomian masyarakat setempat melalui produksi kuliner asli Bali yang sehat dan berkualitas kepada masyarakat, wisatawan domestik dan wisatawan asing, sebagai salah satu usaha peningkatan mutu kehidupan secara umum melalui peningkatan sanitasi penjualan daging babi.

\section{METODE PENELITIAN}

\section{Sampel}

Sampel daging babi sebanyak 26 sampel dengan berat masing-masing 250 Gr diambil dari pasar tradisional di Kecamatan Abiansemal dan Kuta, Badung. Sebaran sampel terdiri atas 22 sampel dari Kecamatan Abiansemal meliputi pasar Tegal, Tenten, Sibang Gede, Mambal, Penarungan, dan Blahkiuh dan 4 sampel daging babi dari Kecamatan Kuta meliputi Kuta 1 dan Kuta 2. Setiap sampel diproses secara aseptis mengacu pada Yadung et al. (2016) dan dilakukan uji cemaran bakteri dan residu antibiotik di Laboratorium Kesehatan Masyarakat Veteriner Balai Besar Veteriner (BBVet) Denpasar.

\section{Data Kuisioner}

Pengukuran pengetahuan higiene dan sanitasi responden menggunakan 20 pertanyaan terkait pengetahuan akan higiene dan sanitasi pada saat berjualan daging babi di pasar tradisional. Pengetahuan responden dikuantifikasi dengan memberikan nilai yang mengacu pada metode Khan et al. (2013) dengan beberapa modifikasi. Pengukuran praktik higine dan sanitasi dilakukan berdasarkan 11 pertanyaan penilaian.

\section{Uji Cemaran Bakteri}

Total plate count (TPC)

Sampel ditimbang sebanyak 25 gram, ditambah buffer peptone water (BPW) $0,1 \%$ dan dihomogenkan, serta dibuat pengenceran seri berkelipatan 10 . Kemudian dituangkan ke plate count agar dan diinkubasikan. Koloni yang tumbuh dihitung sebagai total bakteri (BSN, 2008).

\section{Escherichia coli}

Pengujian bakteri E. coli dilakukan dengan mengambil 1 loop dari setiap tabung lauryl sulphat tryptose broth (LSTB) yang positif ke tabung EC broth yang berisi tabung durham. Uji peneguhan dilakukan dengan media Levine EosinMethylene Blue (L-EMB) dan PCA miring untuk uji morphologi dan biokimia. Bakteri E. coli dihitung dengan nilai MPN berdasarkan jumlah tabung dalam pengenceran EC broth yang positif (BSN, 2008).

\section{Staphylococcus aureus}

Sampel dibuat pengenceran $10^{-1}, 10^{-2}$, $10^{-3}$. Masing-masing larutan diinokulasikan pada media BPW diisi egg yolk tellurite emultion. Koloni yang memiliki khas $S$. aureus ditandai dan diambil beberapa untuk uji identifikasi dengan uji koagulase (BSN, 2008).

\section{Salmonella spp.}

Uji dilakukan dengan metode prapengayaan, pengayaan, isolasi dan identifikasi. Pra-pengayaan dengan Lactose Broth (LB), pengayaan dengan media Tetrahionate Broth (TTB). Isolasi dilakukan dengan media selektif Hektoen enteric (HE), Xylose Lysine Desoxycholate agar (XLD) dan Bismuth Sulfide (BSA). Identifikasi dilakukan pada media Triple Sugar Iron Agar (TSIA) dan Lysine Iron Agar (LIA). Koloni dari media TSIA diinokulasikan pada media SCA, Urea Broth dan Sulfide Indol Motility (SIM) agar. (BSN, 2008).

\section{Campylobacter spp.}

Uji dilakukan dengan metode prapengayaan, pengayaan, isolasi dan identifikasi. Pra-pengayaan dengan media enrich broth. Pengayaan dilakukan dengan cara menaikkan suhu inkubasi. Isolasi dilakukan pada media agar modified Campy blood-free Agar (mCCDA). Koloni dengan ciri pertumbuan bakteri Campylobacter spp. diambil dan siap diamati (BSN, 2008). 


\section{Uji Residu Antibiotik}

Pengujian dilakukan dengan metode tapis secara bioassay berdasarkan (SNI 7424:2008) (BSN, 2008). Pembuatan larutan baku pembanding penisilin konsentrasi $1.000 \mathrm{IU} / \mathrm{ml}$. Larutan baku pembanding tetrasiklin konsentrasi 1.000 $\mu \mathrm{g} / \mathrm{ml}$. Pembuatan kurva baku dengan $B$. stearthermophilus untuk penisilin dan $B$. cereus untuk tetrasiklin. Sampel supernatan gerusan daging babi digunakan untuk larutan uji residu antibiotik.

\section{HASIL DAN PEMBAHASAN}

Hasil uji TPC menunjukkan sebanyak $30,76 \%(8 / 26)$ memiliki nilai total mikroba di atas batas maksimum cemaran mikroba, sedangkan sebanyak 69,24\% (18/26) sesuai (SNI)-7388-2009 yaitu $\leq 1 \times 10^{6}$ koloni/gram. Persentase nilai TPC di Kecamatan Abiansemal sebanyak 63,64\% $(14 / 22)$ sesuai standar dan 36,36\% (8/22) melebihi standar, sedangkan di Kecamatan Kuta $100 \%$ (4/4) sesuai standar. Rerata total bakteri TPC adalah 3,7 x $10^{5}$ dengan kisaran $7,3 \times 10^{3}$ hingga $1,5 \times 10^{6}$ koloni/gram terlihat pada Tabel 1 .

Tabel 1. Rerata total bakteri (koloni/gram) pada daging babi $(n=26)$ dijual di pasar tradisional di wilayah Kecamatan Abiansemal dan Kuta Kabupaten Badung.

\begin{tabular}{cccccc}
\hline No. & Kecamatan & Lokasi Pasar & $\begin{array}{c}\text { Jumlah } \\
\text { Pasar }\end{array}$ & $\begin{array}{c}\text { Hasil Rerata } \\
\text { (koloni/gram) }\end{array}$ & Keterangan \\
\hline 1. & Abiansemal & Tegal & 3 & $5,2 \times 10^{5}$ & sesuai ambang batas \\
& & Tenten & 1 & $9,7 \times 10^{3}$ & sesuai ambang batas \\
& & Sibang Gede & 1 & $1,6 \times 10^{5}$ & sesuai ambang batas \\
& & Mambal & 4 & $3,7 \times 10^{5}$ & sesuai ambang batas \\
& & Penarungan & 2 & $7,3 \times 10^{3}$ & sesuai ambang batas \\
& & Blahkiuh & 11 & $1,5 \times 10^{6}$ & $*>$ ambang bata \\
2. & Kuta & Kuta A & 3 & $3,9 \times 10^{5}$ & sesuai ambang batas \\
& & Kuta B & 1 & $3,3 \times 10^{4}$ & sesuai ambang batas \\
\hline
\end{tabular}

Keterangan: $\left(^{*}\right)=$ Melebihi standar persyaratan SNI-7388-2009 yaitu $\geq 1 \times 10^{6}$ koloni/gram.

Rerata nilai TPC melebihi batas ambang standar cemaran mikroba di pasar tradisional Blahkiuh pada penelitian ini dapat disebabkan karena memiliki perbedaan sikap dan prilaku serta pemahaman terhadap pentingnya higiene dan sanitasi lingkungan. Dilihat dari aspek kesehatan masyarakat veteriner menunjukkan bahwa daging yang berasal dari blahkiuh tidak layak untuk dikonsumsi, sehingga disarankan penjual daging babi untuk menjaga kebersihan dan sanitasi di lingkungan pasar tradisional Blahkiuh. Selain itu, nilai TPC yang tinggi dari standar diketahui berkaitan dengan lingkungan yang tidak higienis serta dapat menimbulkan adanya mikroorganisme patogen dalam daging (Hassan et al., 2010). Nilai TPC ini lebih tinggi dibandingkan dengan yang dilaporkan oleh Kim et al.
(2018) pada monitoring cemaran bakteri pada daging babi di Korea didapat nilai TPC berkisar antara $10^{1}$ hingga $10^{7}$ koloni/gram. Secara umum kondisi sanitasi pasar dan tempat penjualan daging pada umumnya memang jauh lebih baik bila dibandingkan dengan pasar tradisional di Abiansemal dan Kuta.

Menurut Manios et al. (2015) nilai TPC sangat dipengaruhi oleh beberapa faktor seperti suhu yang tinggi $\left(>15^{\circ} \mathrm{C}\right)$ dan kondisi sanitasi dan tatacara penjualan daging, semakin kurang memenuhi syarat sanitasi maka pada umumnya juga semakin tinggi beban total bakteri pada daging. Pada penelitian ini membuktikan diantaranya sikap penjual daging babi di kecamatan Abiansemal dan Kuta tidak memisahkan daging babi dan jeroannya dalam meja yang berbeda, pedagang tidak selalu 
membersihkan meja tempat berjualan sebelum dan setelah berjualan dengan air bersih dan sabun, pedagang menggunakan pisau yang sama saat memotong jeroan dan daging babi, pedangang tidak rutin membersihkan tempat jualan, dan pedagang tidak memiliki baju khusus untuk berjualan daging babi di pasar. Sedangkan di negara-negara Asean bahkan sudah hampir semua pedagang daging babi telah mengikuti peraturan yang ditentukan oleh pemerintah setempat bahkan beberapa negara seperti Jepang dan Korea Selatan telah menerapkan standar yang berlaku secara internasional.

Hasil uji Coliform menunjukkan $92,31 \%(24 / 26)$ memiliki nilai total mikroba di atas batas maksimum $\left(1 \times 10^{2}\right.$ koloni/gram), sedangkan 7,69\% (2/26) sesuai (SNI)-7388-2009. Sampel di
Kecamatan Abiansemal 91\% (20/22) melebihi standar dan 9\% (2/22) sesuai standar, sedangkan di Kecamatan Kuta $100 \%$ (4/4) melebihi standar cemaran mikroba. Rerata cemaran Coliform adalah $1,3 \times 10^{5}$ dengan kisaran $1,1 \times 10^{3}$ hingga $4,4 \times 10^{5}$ koloni/gram tersaji pada Tabel 2 . Pada uji cemaran Escherichia coli menunjukkan $92,31 \% \quad(24 / 26)$ memiliki nilai total mikroba di atas batas maksimum cemaran mikroba $\left(1 \times 10^{1} \mathrm{koloni} / \mathrm{gram}\right)$ dan $11,5 \% \quad(3 / 26)$ sesuai (SNI)-7388-2009. Sampel di Kecamatan Abiansemal 86,4\% (19/22) melebihi standar dan 13,6\% (3/22) sesuai standar, sedangkan di Kecamatan Kuta $100 \%$ (4/4) melebihi standar. Rerata mikroba Eschericia coli adalah 2,1 x $10^{4}$ dengan kisaran 4,5 × $10^{1}$ hingga $9,7 \times 10^{4}$ koloni/gram tersaji pada Tabel 2.

Tabel 2. Rerata cemaran Coliform (koloni/gram) pada daging babi dijual di pasar tradisional di wilayah Kecamatan Abiansemal dan Kuta Kabupaten Badung.

\begin{tabular}{cccccc}
\hline No. & Kecamatan & Lokasi Pasar & $\begin{array}{c}\text { Jumlah } \\
\text { Pasar }\end{array}$ & $\begin{array}{c}\text { Rerata Coliform } \\
\text { (koloni/gram) }\end{array}$ & $\begin{array}{c}\text { Rerata E. coli } \\
\text { (koloni/gram) }\end{array}$ \\
\hline 1. & Abiansemal & Tegal & 3 & $1,0 \times 10^{5^{*}}$ & $9,2 \times 10^{3^{* *}}$ \\
& & Tenten & 1 & $4,4 \times 10^{5^{*}}$ & $4,0 \times 10^{4^{* *}}$ \\
& & Sibang Gede & 1 & $3,1 \times 10^{5^{*}}$ & $1,7 \times 10^{4^{* *}}$ \\
& Mambal & 4 & $3,7 \times 10^{4^{*}}$ & $4,5 \times 10^{3^{* *}}$ \\
& & 2 & $1,1 \times 10^{3^{*}}$ & $6,0 \times 10^{2^{* *}}$ \\
& & Penarungan & 11 & $1,5 \times 10^{5^{*}}$ & $9,7 \times 10^{4^{* *}}$ \\
& Blahkiuh & & $2,3 \times 10^{4^{*}}$ & $6,7 \times 10^{1^{* *}}$ \\
& \multirow{2}{*}{ Kuta } & Kuta A & 3 & $1,2 \times 10^{3^{*}}$ & $4,5 \times 10^{1^{* *}}$ \\
\hline
\end{tabular}

Keterangan: (*): Melebihi standar persyaratan SNI-7388-2009 yaitu $\geq 1 \times 10^{2}$ koloni/gram.

(**): Melebihi standar persyaratan SNI-7388-2009 yaitu $\geq 1 \times 10^{1} \mathrm{koloni} / \mathrm{gram}$.

Bakteri Coliform dan E. coli yang melebihi standar pada penelitian ini merupakan indikator kurangnya kualitas kebersihan dan sanitasi penjual daging babi. Bakteri E. coli dengan jumlah di atas standar dilaporkan menjadi peluang terjadinya foodborne disease dan munculnya flora bakteri patogen lainnya (Oswar et al., 2014). Adanya bakteri Coliform sebagai indikasi bahwa terjadi kontaminasi dengan lingkungan sekitar (Martin et al., 2016). Prevalensi Coliform dan E. coli pada penelitian ini lebih tinggi dari studi sebelumnya oleh Bantawa et al.
(2018). Berdasarkan aspek kesehatan msyarakat veteriner bahwa daging babi yang dijual di pasar tradisional di Kecamatan Abiansemal dan Kuta tidak layak untuk dikonsumsi.

Hasil cemaran Salmonella sp. menunjukkan sebanyak $0 \%(0 / 26)$ atau negatif cemaran bakteri Salmonella $s p$. Kontaminasi daging babi dengan Salmonella dapat ditemukan sepanjang rantai produksi daging babi (FajardoGuerrero et al., 2020). Penelitian ini menunjukkan bahwa angka prevalensi cemaran Salmonella sp. 0\% pada sampel 
daging babi yang diambil di pasar tradisional. Hal ini menunjukkan bahwa meskipun nilai rerata TPC, Coliform dan $E$. coli melebihi ambang batas, namun ancaman kemungkinan konsumen terserang radang typhus hampir tidak ada karena semua sampel tidak ditemukan adanya kontaminan Salmonella. Prendergast et al. (2009) melaporkan juga rendahnya nilai prevalensi $(2,6 \%)$ kontaminasi daging babi oleh Salmonella $s p$. dari sampel yang diambil dari penjual di Irlandia. Tidak ditemukannya cemaran Salmonella sp. pada penelitian ini dapat terkait dengan tidak adanya kasus Salmonellosis pada babi di wilayah Kabupaten Badung sebagai asal babi yang dipotong dan diperjual belikan dan juga terkait dengan rendahnya tingkat kejadian penyakit typhus pada manusia pada saat pengambilan sampel. Mengingat bahwa Salmonella sp. bisa ditularkan dari manusia ke babi (Argüello et al., 2013).

Uji cemaran $S$. aureus menunjukkan $0 \%(0 / 26)$ nilai cemaran mikroba di atas (SNI)-7388-2009 yaitu 1 x $10^{2}$ koloni/gram. Penelitian ini menunjukkan cemaran $S$. aureus daging babi yang dijual tidak melebihi batas cemaran. Cemaran $S$. aureus pada daging babi yang melebihi standar dapat menimbulkan ancaman bagi manusia karena $S$. aureus dapat menghasilkan enterotoksin pada daging babi yang terkontaminasi dengan racun yang terbentuk sebelumnya (Hennekinne $e t$ al., 2012).

Hasil cemaran Campylobacter sp. menunjukkan $0 \%(0 / 26)$ atau negatif Campylobacter sp. Campylobacteriosis adalah zoonosis bawaan makanan yang paling umum di seluruh dunia. Penelitian lain melaporkan prevalensi cemaran Campylobacter $s p$. pada daging babi bervariasi di beberapa negara seperti di Amerika Serikat 1,3\%, Belgia 2\%, dan Kanada 16,9\% (Duffy et al., 2001). Rendah atau tidak adanya cemaran Campylobacter $s p$ pada penelitian ini dapat disebabkan karena kejadian kasus ini jarang terjadi pada babi, sehingga berpengaruh pada tingkat cemaran Campylobacter sp pada daging babi yang dijual di pasar (Zhao et al., 2001).

Uji residu antibiotik 15,38\% (4/26) positif residu antibiotik tetrasiklin dan $11,54 \%(3 / 26)$ positif residu penisilin tersaji pada Tabel 3.

Tabel 3. Hasil uji residu antibiotik tetrasiklin dan penisilin pada daging babi $(n=26)$ dijual di pasar tradisional di wilayah Kecamatan Abiansemal dan Kuta Kabupaten Badung.

\begin{tabular}{ccccc}
\hline No. & Lokasi Pasar & Kecamatan & Residu Tetrasiklin & Residu Penisilin \\
\hline 1. & Tegal & Abiansemal & $0 / 3$ & $0 / 3$ \\
2. & Tenten & Abiansemal & $0 / 1$ & $0 / 1$ \\
3. & Sibang Gede & Abiansemal & $0 / 1$ & $0 / 1$ \\
4. & Mambal & Abiansemal & $0 / 4$ & $0 / 4$ \\
5. & Penarungan & Abiansemal & $0 / 2$ & $0 / 2$ \\
6. & Blahkiuh & Abiansemal & $0 / 11$ & $0 / 11$ \\
7. & Kuta I & Kuta & $3 / 3$ & $2 / 3$ \\
8. & Kuta II & Kuta & $1 / 1$ & $1 / 1$ \\
\hline Jumlah Positif Residu Tetrasiklin & $4 / 26(15,38 \%)$ & $3 / 26(11,54 \%)$ \\
\hline
\end{tabular}

Persentase residu tetrasiklin di pasar tradisional Kecamatan Kuta sebesar 100\% (4/4), sementara di Kecamatan Abiansemal sebesar $0 \%(0 / 22)$. Persentase residu penisilin di pasar tradisional Kecamatan Kuta sebesar $75 \%$ (3/4), sedangkan di Kecamatan Abiansemal 0\% (0/22). Hasil penelitian menunjukkan bahwa di pasar tradisional Kecamatan Kuta ditemukan lebih banyak residu antibiotik dibandingkan dengan di pasar tradisional Kecamatan Abiansemal. Hal itu kemungkinan sangat berkaitan dengan asal daging babi yang diambil dari RPH 
Pesanggaran. RPH Pesanggaran merupakan salah satu RPH yang terletak di perkotaan dan disekitar RPH tersebut terdapat banyak peternak babi yang berasal dari wilayah Sesetan dan Pedungan yang umumnya mereka mencoba mengobati babinya bila terlihat sakit dengan memberikan obat-obat jenis antibiotik yang diperoleh dari toko obat tanpa resep dokter hewan untuk menekan biaya pemeliharaan babi. Hal ini menjadi salah satu faktor adanya residu yang ditemukan dari daging babi di pasar tradisional Kuta. Sementara, di Kecamatan Abiansemal tidak ditemukan adanya residu antibiotik, hal ini karena adanya kelompok ternak babi yang secara rutin mengadakan pertemuan yang aktif untuk memajukan usaha peternakan babi dan mengedukasi masyarakat tentang penggunaan antibiotik yang dilakukan oleh dokter hewan setempat yang bertugas membina peternak babi. Hal ini berbeda dengan peternakan di sekitar kota atau di wilayah Kuta yang sudah sangat padat penduduknya dan akses yang relatif mudah untuk mendapatkan obat-obatan.

Residu antibiotik tetrasiklin dan penisilin dalam daging tergantung pada dosis awal dan durasi antara pemberian antibiotik dan pemotongan hewan/ternak, selain itu kurangnya pemahaman peternak dalam penggunaan antibiotik tetrasiklin sesuai dengan masa henti obat (withdrawal time) (Donkor et al., 2011). Yamaguci et al. (2015) melaporkan 8,8\% daging babi yang berasal dari rumah pemotongan hewan dan pasar di Vietman selama 20122013 mengandung residu antibiotik yang disebabkan ketidaktepatan para peternak akan masa henti antibiotik. Menurut Rakotoharinome et al. (2014) babi dalam masa penyembuhan dan didahulukan untuk dijual di Rumah Pemotongan Hewan juga memberikan dampak ditemukannya residu antibiotik daging babi di Rumah Pemotongan Hewan sebesar $(34,4 \%)$ dan $(42,2 \%)$.

Hasil kuisioner pengetahuan terkait higiene dan sanitasi dalam kategori kurang hingga cukup. Sebanyak 50\% (13/26) penjual dengan kategori kurang dan $50 \%$ (13/26) dengan kategori cukup. Hasil penelitian menunjukkan bahwa ditemukan 4 (empat) aspek sebagai titik kritis pengetahuan yang salah terkait higiene dan sanitasi yaitu penyatuan penjualan daging babi dan jeroannya, penggunaan pisau bersama untuk daging babi dan jeroannya, penggunaan talenan yang terbuat dari kayu, dan pakaian khusus untuk berjualan daging babi di pasar.

Pengetahuan higiene dan sanitasi dalam penjualan daging babi merupakan suatu komponen penting untuk menunjang terlaksananya penerapan tindakan higiene dan sanitasi produk asal hewan pada lingkungan pasar tradisional. Menurut Mallhi et al. (2018) dan Yenealem et al. (2020) pengetahuan yang buruk atau kurang tentang higine dan sanitasi penjual daging dapat berpengaruh terhadap buruknya tindakan higiene dan sanitasi serta berdampak juga pada tingginya cemaran mikroba pada daging berdasarkan standar WHO. Pengetahuan higine dan sanitasi penjual daging di pasar tradisional umunya di pengaruhi oleh beberapa faktor seperti usia, tingkat pendidikan, pengalaman berdagang, dan sosialisasi (Sidabalok et al., 2015).

Hasil penilaian tindakan higiene dan sanitasi pada penelitian ini dalam kategori kurang hingga baik. Sebanyak 7,7\% (2/26) penjual daging dengan kategori baik, 80,8\% (21/26) kategori cukup dan 11,5\% (3/26) dengan kategori kurang. Ditemukan 5 (lima) aspek sebagai titik kritis tindakan praktik higiene dan sanitasi penjual daging pada penelitian ini yaitu penjual menggunakan pisau yang sama saat memotong jeroan dan daging babi, penjual tidak memisahkan daging babi dan jeroannya dalam meja yang berbeda, penjual tidak selalu membersihkan meja tempat berjualan sebelum dan setelah berjualan dengan air bersih dan sabun, penjual tidak rutin membersihkan tempat jualan, dan penjual tidak memiliki baju khusus untuk berjualan daging babi di pasar. 
Tindakan praktik higiene dan sanitasi terhadap bahan pangan asal hewan yang benar dapat mencegah kontaminasi daging dari mikroba dan bahan kimia yang menjadi masalah kesehatan (WHO, 2015). Menurut Mayer et al. (2010) selama proses berjualan daging kontaminasi dapat terjadi melalui kontak dengan peralatan seperti meja, pisau, talenan, serangga, udara, dan konsumen. Tindakan penanganan daging yang benar oleh penjual merupakan peran yang penting dalam mengendalikan patogen yang ditularkan dari peralatan yang terkontaminasi seperti E. coli, Salmonella, $S$. aureus dan patogen yang lain (Havelaar et al., 2013).

\section{SIMPULAN DAN SARAN}

\section{Simpulan}

Daging babi yang dijual di pasar tradisional Kecamatan Kuta dan Abiansemal, Badung memiliki nilai TPC $34,61 \%$ melebihi batas maksimal yang diijinkan. Cemaran Coliform dan E. coli $90,2 \%$ di atas batas maksimum cemaran mikroba. Tidak ditemukan adanya cemaran S. aureus, Salmonella sp dan Campylobacter sp. Residu antibiotika $15,38 \%$ daging mengandung Tetrasiklin dan $11,54 \%$ Penisilin. Pemahaman penjual tentang higiene dan sanitasi adalah $(50 \%)$ paham dan (50\%) kurang paham dan sadar tentang sanitasi. Faktor-faktor mempengaruhi tingkat cemaran bakteri adalah peralatan yang digunakan yaitu penjual menggunakan pisau yang sama saat memotong jeroan dan daging babi, tidak memisahkan daging babi dan jeroannya dalam meja yang berbeda, tidak selalu membersihkan meja tempat berjualan sebelum dan setelah berjualan dengan air bersih dan sabun, tidak rutin membersihkan tempat jualan, dan tidak memiliki baju khusus untuk berjualan daging babi di pasar.

\section{Saran}

Disarankan untuk peningkatan edukasi masyarakat terhadap kesehatan dan sanitasi khususnya kepada penjual daging babi oleh instansi atau dinas terkait kesehatan masyarakat veteriner untuk meningkatkan mutu kesehatan daging babi yang dijual.

\section{UCAPAN TERIMA KASIH}

Penulis mengucapkan terima kasih kepada Kepala Balai Besar Veteriner beserta Pegawai yang bertugas di Laboratorium Kesehatan Masyarakat Veteriner atas ijin dan kesempatan yang diberikan dalam pelaksanaan penelitian.

\section{DAFTAR PUSTAKA}

Argüello H, Alvarez-Ordoñez A, Carvajal A, Rubio P, Prieto M. 2013. Role of slaughtering in Salmonella spreading and control in pork production. J. Food Protection. 76: 899-911.

Arief RA, Darmawan RD, Sunandar, Widyastuti MDW, Nugroho E, Jatikusumah A, Putra AAG, Basuno E, Kurniawati A, Suwandono A, Wilyanto I, Suandy I, Latif H. 2016. Penggunaan antibiotik pada peternakan babi di Provinsi Jawa Tengah Indonesia. Proc. KIVNAS 14: 261-263.

Baer AA, Miller MJ, dan Dilger AC. 2013. A Rivew of Research on Interventions to Assure Food Safety. Comp. Rev. Food Sci. Food Safety. (12): 183-217.

Bantawa K, Rai K, Limbu DS, Khanal H. 2018. Food-borne bacterial pathogens in marketed raw meat of Dharan, eastern Nepal. BMC Res Note. 11(618): 1-5.

BSN (Badan Standar Nasional). 2009. Standar Nasional Indonesia (SNI)7388-Tentang Batas Maksimum Cemaran Mikroba dan Batas Maksimum Residu dalam Bahan Makanan Asal Hewan. Jakarta: Badan Standardisasi Nasional.

BSN (Badan Standar Nasional). 2008. Standar Nasional Indonesia (SNI) 2897:2008 tentang Metode pengujian cemaran mikroba dalam daging, telur dan susu, serta hasil olahannya. Jakarta (ID): Badan Standarisasi Nasional. 
Dewey-Mattia D, Manikonda K, Hall AJ, Wise ME, Crowe SJ. Surveillance for foodborne disease outbreaks-United States, 2009-2015. 2018. Surveillance Summaries. 67(10): 1-11.

Do MHN, Yamaguchi T, Okihashi M, Harada K, Konishi Y, Uchida K, Bui LT, Nguyen TD, Phan HB, Bui HDT, Nguyen PD, Kajimura K, Kumeda Y, Dang CV, Hirata $\mathrm{K}$, Yamamoto $\mathrm{Y}$. 2016. Screening of antibiotic residues in pork meat in Ho Chi Minh City, Vietnam, using a microbiological test kit and liquid chromatography/tandem mass spectrometry. Food Control. 69: 262-266.

Donkor ES, Newman MJ, Tay SCK, Dayie NTKD, Bannerman E, Olu-Taiwo M. 2011. Food Control. 22(6): 869-873.

Duffy EA, Belk KE, Sofos JN, Bellinger GR, Pape A, Smith GC. 2001. Extent of microbial contamination in United States pork retail products. J. Food Prot. 64: 172-178.

Fajardo-Guerrero M, Rojas-Quintero C, Chamorro-Tobar I, Zambrano C, Sampedro F, Carrascal-Camacho A. 2020. Exposure assessment of Salmonella spp. in fresh pork meat from two abattoirs in Colombia. Food Sci. Technol. Int. 26(1): 21-27.

Hassan AN, Farooqui A, Khan A, Khan AY, Kazmi SU. 2010. Microbial contamination of raw meat and its environment in retail shops in Karachi, Pakistan. J. Infect. Develop. Count. 4(6): 382-388.

Hennekinne JA, De Buyser ML, Dragacci S. 2012. Staphylococcus aureus and its food poisoning toxins: characterization and outbreak investigation. FEMS Microbiol. Rev. 36: 815-836.

Khan HA, Akram W, Shad SA, Razaq M, Naeem-Ullah U, Zia K. 2013. A cross sectional survey of knowledge, attitude and practices related to house flies among dairy farmers in Punjab, Pakistan. J. Ethnobiol. Enthnomed. 9:18-28.
Kim JH, Hur SJ, Yim DG. 2018. Monitoring of Microbial Contaminants of Beef, Pork, and Chicken in HACCP Implemented Meat Processing Plants of Korea. Korean Soc. Food Sci. Anim. Res. 38(2): 282-290.

Mallhi IY, Sohaib M, Khan AU, Nawaz M, Abdullah. 2018. Evaluating food safety knowledge, practices, and microbial profile of meat in abattoirs and butchery shops in Lahore, Pakistan. J. Food Safety. 39(2): 1-7.

Manios SG, Grivokostopoulos NC, Bikoili VC, Doultsos DA, Zilelidou EA, Gialitako MA, Skandamis PN. 2015. A 3-year hygiene and safety monitoring of a meat processing plant which uses raw materials of global origin. Int. J. Food Microbiol. 209: 60-69.

Marni S, Marzura MR, Eddy AA, Sulaiman AK. 2017. Veterinary Drug Residues in Chicken, Pork and Beef in Peninsular Malaysia in the period 2010-2016. Malaysian J. Vet. Res. 8(2): 71-77.

Martin NH, Trmc 'ic' A, Hsieh T, Boor KJ, Wiedmann M. 2016. Front Microbiol. 7(1549): 1-8.

Meyer C, Thiel S, Ullrich U, Stolle A. 2010. Salmonella in raw meat and byproducts from pork and beef. J. Food Protection. 73(10): 1780-1784.

Oswar JA, Kikuvi G, Kariuki JN, Kariuki S. 2014. A cross-sectional study on the microbiological quality and safety of raw chicken meats sold in Nairobi, Kenya. BMC Res. Notes. 7 (627):1-8.

Prendergast DM, Duggan SJ, GonzalesBarron U, Fanning S, Butler F, Cormican M, Duffy G. 2009. Prevalence, numbers and characteristics of Salmonella spp. on Irish retail pork. Int. J. Food Microbiol. 131(2-3): 233-239.

Rakotoharinome M, Pognon D, Randriamparany T, Ming JC, Idoumbin JP, Cardinale E, Porphyre V. 2014. Prevalence of antimicrobial residues in pork meat in Madagascar. Trop. Anim. Health Prod. 46(1): 49-55. 
Sidabalok HA, Lukman DW, Purnawarman T. 2015. Karakteristik dan Pengetahuan Higine Sanitasi Pedagang Daging Ayam di Pasar Tradisional di Kota Jakarta. J. Kedokteran Hewan. 9(1): 6163.

WHO (World Health Organization). 2015. Food safety: What you should know. https://apps.who.int/iris/handle/10665/ 160165. Diakses tanggal 5 Mei 2020.

Yadung III RS, Jr Ventura DC, Ybanez RHD, Ybanez AP. 2016. Microbial plate count and detection of Escherichia coli in pork meat samples from stalls in a public wet market in Cebu, Philippines. Int. Res. J. Interdis. Multidis. Stud. 2(2): 65-72.

Yamaguchi T, Okihashi M, Harada K, Konishi Y, Uchida K, Do MHN, Bui HDT, Nguyen PD, Chau VV, Dao KTV, Nguyen HTN, Kajimura K,
Kumeda Y, Bui CT, Vien MQ, Le NH, Hirata K, Yamamoto Y. 2015. Antibiotic Residue Monitoring Results for Pork, Chicken, and Beef Samples in Vietnam in 2012-2013. J. Agric. Food Chem. 63(21): 5141-5145.

Yenealem DG, Yallew WW, Abdulmajid S. 2020. Food Safety Practice and Associated Factors among Meat Handlers in Gondar Town: A CrossSectional Study. J. Environ. Pub. Health. 2020: 1-7.

Zhao C, Ge B, De Villena J, Sudler R, Yeh E, Zhao S, White DG, Wagner D, Meng J. 2001. Prevalence of Campylobacter spp., Escherichia coli, and Salmonella serovars in retail chicken, turkey, pork, and beef from the Greater Washington, D.C. Area. Appl. Environ. Microbiol. 67(12): 5431-5436. 